\title{
イヌ胃における近側胃切除術後の筋電図学的研究
}

\author{
徳島大学医学部 第一外科学教室 \\ (主任： 古味信彦教授) \\ 古根川 龍 司

\section{ELECTROMYOGRAPHICAL STUDY ON THE RESIDUAL STOMACH FOLLOWING PROXIMAL GASTRECTOMY} \\ Ryuzi Konegawa
}

First Department of Surgery, School of Medicine, University of Tokushima

(Director : Prof. N. Komi)

The role of the antral gastric vagi and the pyloric sphincter on the residual stomach following proximal gastrectomy were studied electromyographically, using adult mongrel dogs. At the first stage of surgery, proximal gastrectomy was performed preserving the bilateral antral gastric vagi followed by esophagogastrostomy by end-to-side anastomosis. The residual stomach was equipped with four bipolar silber needle electrodes and two waterproof strain guages on the wall of the stomach.

At the second and thrid stage of surgery, the same dog subsequently underwent trancal vagotomy and pyloromyotomy at 4 weeks intervals.

Following proximal vagotomy, the interval of the BER in fasting was prolonged. Dysrhythmia was observed quite frequently, and the amplitude and rhythmicity of contractile activities of the residual stomach became lowered and distorted, however, after feeding the interval of the EBR was shortened and dysrhythmia was altered to a regular rhythmic pattern.

Frequent episodes of vomiting were observed following over feeding.

Subsequent trancal vagotomy showed increased incidence of dysrhythmia in fasting, and gave no favourable effects on the vomiting episodes or the amount of feeding. After pyloromyotomy, the amount of feeding could be increased by about $50 \%$ from the original optimal amount.

は じ

近側胃切除術は, 本邦では久留, 水上 (1952), 砂田（1952），および村上ら（1956）によって提 唱され，欧米でも時期を同じくして Leger (1953) や Holle ら（1955）によって行われていた。 以 来多くの手術法, 治療成績, 及び実験的研究が発 表されている。この手術後にはしばしば逆流性食 道炎, 與葆下障害, 残胃内容の排出障害等の術後障 害がみられるが，これらの障害の原因として Tanner ら（1951）は迷走神経切離による残胃の
め に

アトニーを考光，また Franke（1959）は幽門病 戀を重視している。また実験的には近側胃切除術 後障害の原因を筋電図学的に観察した橿（1965）, 鳴海（1964），渡辺（1959）等の 報告がみられる が必ずしも明解な結果が得られたとはいえない。 著者はイヌ胃を用いた慢性実験によって近側胃切 除術後の残胃の運動を筋電図学的に観察し, これ に及ぼす迷走神経幽門洞技の温存, 及び幽門形成 術の影響に関して興味ある所見を得たので報告す 
る。

\section{実験方 法}

実験動物としては体重 $10 \mathrm{~kg}$ 前後の健康な雑種 成犬を用いた。ラボナール $30 \mathrm{mg} / \mathrm{kg}$ の静脈麻酔 にて無菌的に上腹部の正中切開で開腹し,ついで 選択的近位迷走神経切離術を行った上さらに近側 胃切除術を加えた。切除範囲の決定は図 1 に示す ように, 食道部切離は食道胃移行部より口側約 1 $\mathrm{cm}$ の部とした。また胃側切離は小彎側では迷走 神経幽門洞枝の幽門洞部への進入点より約 $1 \mathrm{~cm}$ 口側, 大彎側では左胃大網動静脈の最終技が胃壁 に進入する部位より $1 \mathrm{~cm}$ 口側で，これらを結ぶ 線上で行った。

食道胃昒合は図 2 亿示すように残胃前壁で行っ た。この際幽門洞技を損傷しないよう配慮した。 ついで自家考案の双極電極（極間 $1.5 \mathrm{~mm}$, 極間 抵抗 $25 \mathrm{k} \Omega$ ）を胃壁に縫着した。電極 $\mathrm{E}_{1}$ は口側 胃縫合閉鎖部より約 $1.5 \mathrm{~cm}$ 肛門側にて大彎側寄 りに縫着し，電極 $\mathrm{E}_{4}$ は幽門括約筋部より約 1.5 $\mathrm{cm}$ 口側で大彎側寄りに縫着した。ついで電極 $\mathrm{E}_{1}$ と電極 $\mathrm{E}_{4}$ との間に涪等間隔になるよう $\mathrm{E}_{2}, \mathrm{E}_{3}$ を縫着した。さらに胃壁の収縮状態を記録する目 的で防水型ストレインゲージ（KFW 120.0 0.3 $\Omega$, 共和電業製) $\mathrm{S}_{1}$ を残胃口側に縫着し, $\mathrm{S}_{2}$ を幽

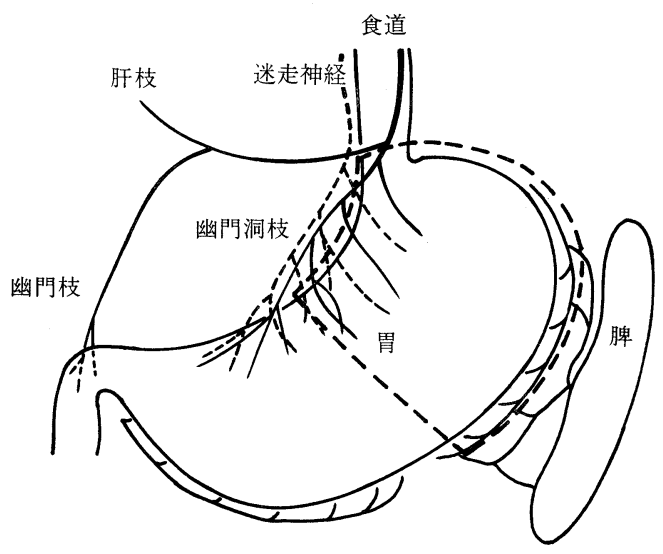

図 1. 近側胃切除範囲 イヌ胃における近側胃切除範囲を破線で示す. 食道胃切離部は食道胃接合部より $1 \mathrm{~cm}$ 口側, 胃 切離部は小彎側では迷走神経幽門洞枝が胃壁に 進入する部位より約 $1 \mathrm{~cm}$ 口側, 大彎側では左胃 大網動静哌の最終枝が胃壁に進入する部位より $1 \mathrm{~cm}$ 口側とした。

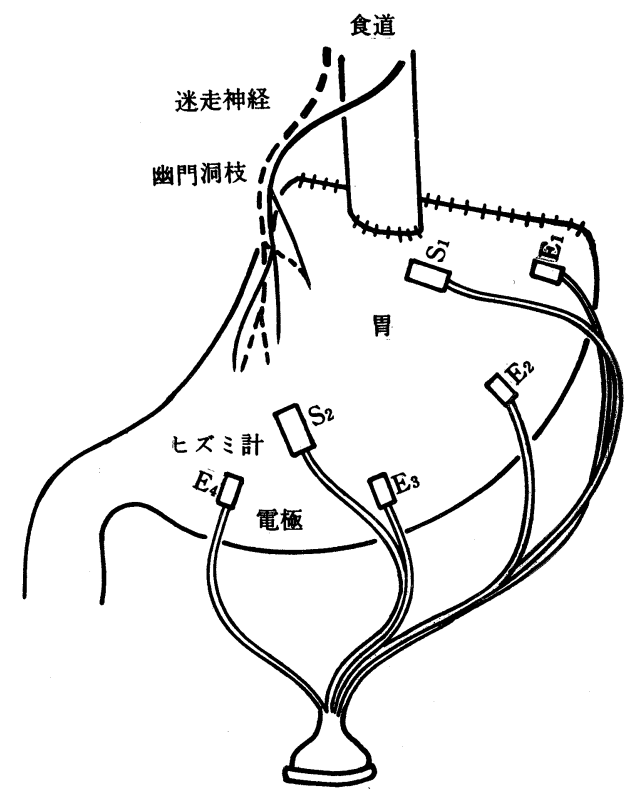

九ピンコネクター

図 2, 食道胃吻合術後電極, 歪計配置図

口側胃縫合閉鎖部より約 $1.5 \mathrm{~cm}$ 肛門側で大彎側 寄りに電極 $\mathrm{E}_{1}$ を，幽門括約筋部より $1.5 \mathrm{~cm}$ 口 側で大彎側寄りに $\mathrm{E}_{4}$ を, これら $\mathrm{E}_{1}, \mathrm{E}_{4}$ 間に等 間隔になるよう $\mathrm{E}_{2} \mathrm{E}_{3}$ を縫着した。残胃口側中 央に歪計 $\mathrm{S}_{1}$ を, 幽門洞部中央に $\mathrm{S}_{2}$ を綘着した.

門洞部中央に縫着した。これらの電極及びストレ インゲージの導線は側腹部より皮下を通して背部 の小皮膚切開口より体外に誘導し，9ピンコネク ターに接続した。接続部は acrylic resin で絶縁 した。

術後イヌが実験食摂食可能になった 1 週間前後 より，16〜24 時間の空腹状態並びに摂食刺激と してドッグフード $100 \mathrm{~g}$ と即席ラーメン $100 \mathrm{~g}$ を 与えた状態で, 直後から経時的に胃筋電図並びに 胃壁収縮状態の記録を行った．幽門洞技が温存さ れていることの確認はイヌにインスリン $0.4 \mathrm{U} / \mathrm{kg}$ 静注して, 胃壁の収縮能がえ進する現象によって 判定した. 近側胃切除術後の観察が終ってから, 同一イヌを用いて約 1 力月後, 左第 7 肋門で開胸 して両側の迷走神経幹の切離（以下, 幹迷切と略 す)を行った. この際迷走神経を約 $1 \mathrm{~cm}$ 切除し, 両断端を絹系で結禁した。さらに幹迷切の 4 週間 
後に幽門形成の目的で幽門輪口側 $2 \mathrm{~cm}$, 肛門側十 二指腸約 $1 \mathrm{~cm}$ の範团で漿膜筋層切離を加えた。 な和幹迷切後, 及び幽門部漿膜筋層切離後の筋電 図並びに胃壁収縮状態の記録の条件は近側胃切除 後におけると同椂に行ない, 約 4 週間のあいだ経 時的に筋電図を記録した。記録には三栄測器製移 動式 4 系統脳波装置 EG-402 にペン描き記録器 を接続したものを用い，時定数は 0.03 秒とした.
機械曲線の記録にはストレインゲージをホイス トンブリッジに連絡し，さらに D.C Amplifier AD2-20 に,ついで上述のペン描き記録器に接続 した．漿膜笳層切離してより約 4 週後に，イヌを ラボナール楣醉下に屠殺し食道末端近くから十二 指腸にかけての残胃を摘出し，中村（1970）の方 法で笳層を露出した。また食道胃移行部の病理組 織学的検索も合わせて行った。

\section{実 験 結 果}

\section{I. 空腹時の筋電図と歪曲線}

近側胃切除を行ったイヌの空腹時の筋電図には

基本的に図 3 , 図 4 のごとく2〜15 分間隔で繰り 返される action potentials を伴った基本的電気

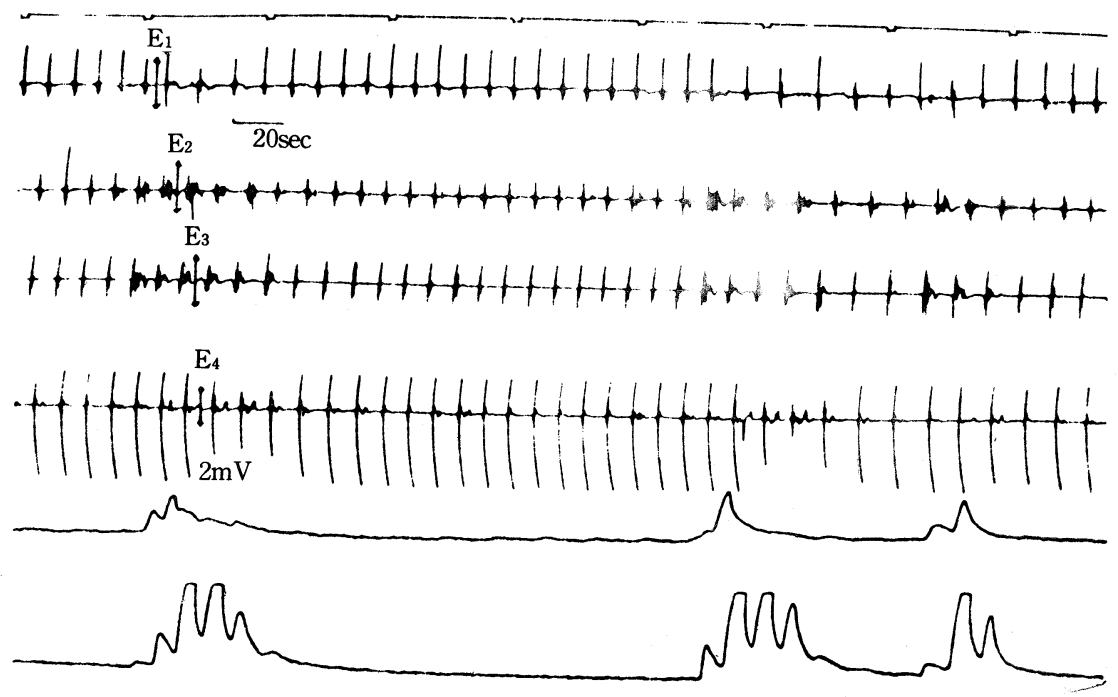

図 3. 近側胃切除術後の空腹時電気活動と胃壁の歪曲線. 術後比較的早期の放電間隔を示す.

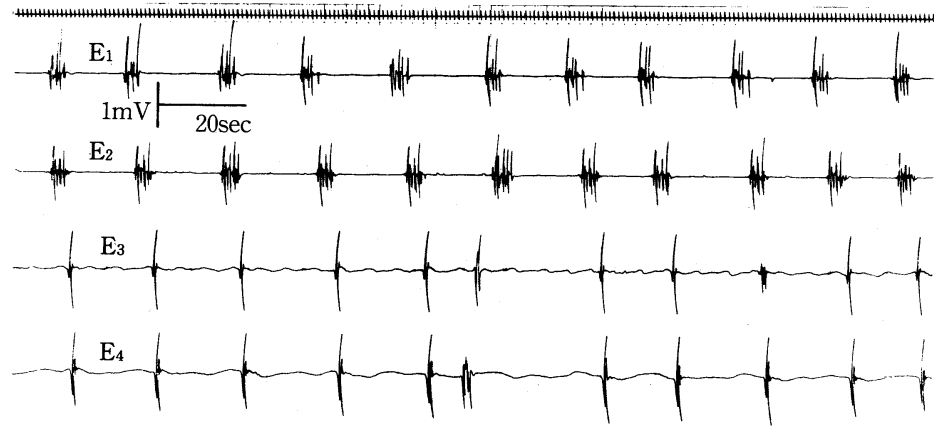

Fasting

Prox + TV + Pyloroplasty

図 4. 近側胃切除, 幹迷切, 幽門部漿膜筋層切離術後の筋電図.

比較的安定した時の筇電図である。放電間隔 20 秒前後々延長をみとめ, またそのバラツキも大きい. Dysrhythmia も一部に認める。 
律動が認められた。このときみられる action potentials は歪曲線上胃壁の収縮運動を反映してい ることが理解できた。図 5 , 図 6 にみられるよう な幽門洞部に phase lead を持つ電気的興奮の乱 れ dysrhythmia (Kelly, 1972) の頻発する現象 がみられた。これらの dysrhythmia が発生する とき, 歪曲線上では胃壁の収縮形式も乱れる一方
微小となる現象がみられた。 dysrhythmia のみら れないときの基本的電気律動の放電間隔を検討す ると，近側胃切除直後では $13.5 \pm 1.5 \mathrm{sec}$ である が, 術後 10 日前後から放電間隔は著明に延長を 示し, dysrhythmia の頻発をみとめた．放電間隔 は約 2 週間後から 3 週間以内には $18.5 \pm 3.6 \mathrm{sec}$ と安定した。表 1 は個々のイヌの放電間隔を示

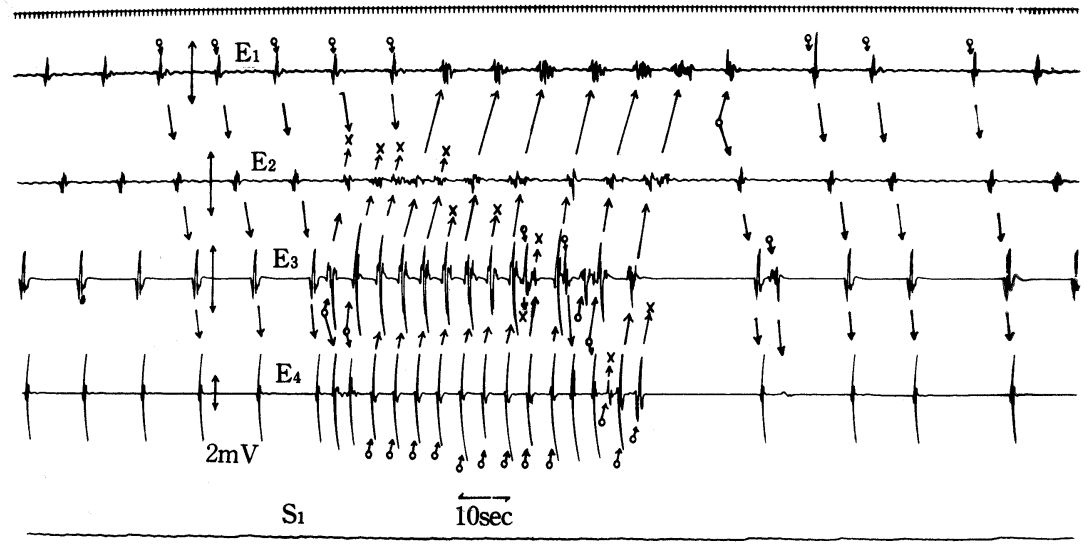

$S_{2}$

図 5. 近側胃切除術後空腹時の筋電図と歪曲線.

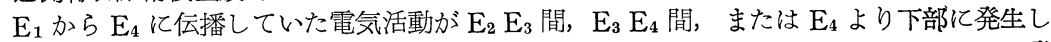
た phase lead そより dysrhythmia が発生しているのがわかる。また dysrhythmia 発 生時には歪曲線上運動は極く微弱であった。

。印は想定される phase lead の位置を示す。

个印は電気活動の伝播方向を示す。

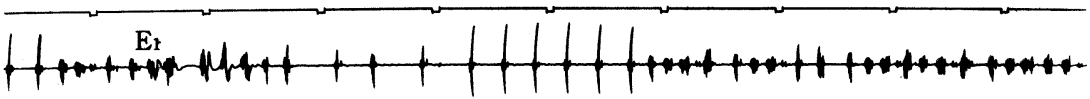

$\mathrm{E}_{2}$
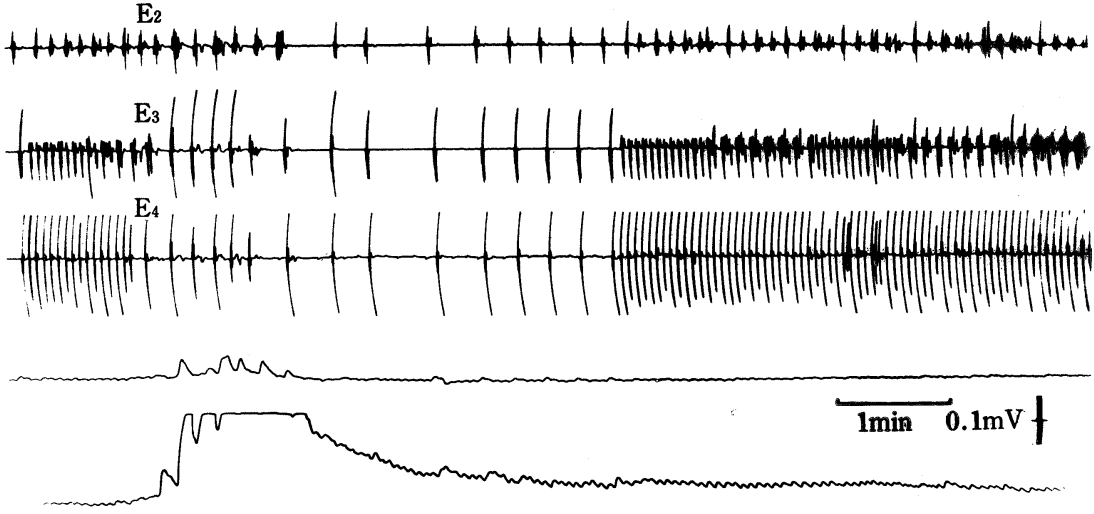

図 6. 近側胃切除術後空腹時の筋電図と歪曲線.

Dysrhythmia の頻発そその時は歪曲線上運動が認められない。 
表 1. 空腹時の放電間隔

\begin{tabular}{l|c|c|c}
\hline & $\begin{array}{c}\text { prox } \\
(\mathrm{sec})\end{array}$ & $\begin{array}{c}\text { prox }+\mathrm{TV} \\
(\mathrm{sec})\end{array}$ & $\begin{array}{c}\text { prox }+\mathrm{TV}+\mathrm{PP} \\
(\mathrm{sec})\end{array}$ \\
\hline Dog 1 & $20.8 \pm 4.4$ & $20.6 \pm 4.8$ & $21.7 \pm 4.1$ \\
Dog 2 & $17.6 \pm 2.9$ & $17.6 \pm 3.3$ & $19.5 \pm 2.4$ \\
Dog 3 & $17.0 \pm 1.2$ & $16.5 \pm 0.7$ & $17.4 \pm 1.8$ \\
\hline 平 均 & $18.5 \pm 3.6$ & $18.2 \pm 4.1$ & $19.5 \pm 3.26$ \\
\hline
\end{tabular}

prox，近側胃切除（迷走神経幽門洞枝温存） prox $+\mathrm{TV}$, 近側胃切除兼幹迷切 prox $+\mathrm{TV}+\mathrm{PP}$ ，近側胃切除兼幹迷切兼幽門部漿膜筋 層切離.

す.これらのイヌに幹迷切を行らと放電間隔は $18.2 \pm 4.1 \mathrm{sec}$ となり，さらに幽門部漿膜筋層切 離術を加えると $19.5 \pm 3.26 \mathrm{sec}$ となったが有意な 差はみられなかった。一方 dysrhythmia につい ては phase lead が $E_{1}$ 以下に求められる場合の 全てを含め, 60 分間の観察期間中に扣ける 全放 電数に対する割合で dysrhythmia の頻度を検討 すると，近側胃切除術直後での dysrhythmia は ほとんど認められないが日時の経過と共に増加 し，10日目より14日目までに最も多く発生し た.しかしその後 dysrhythmia は減少する傾向 を示した。

図 5 , 図 6 は dysrhythmia の笳電図である. $\mathrm{E}_{1}$ より $\mathrm{E}_{4}$ に伝播していた電気活動は新しく $\mathrm{E}_{3}$ $\mathrm{E}_{4}$ 間に, 或いは $\mathrm{E}_{4} よ り 下$ 部に発生した phase leadにより電気的興奮が惹起せられる現象がみら れた。 近側胃切除術後残胃の dysrhythmia の発 生頻度は16.8土13.1\%であった（表 2 ）。このイ
ヌに幹迷切を加えると $40.4 \pm 28.9 \%$ となり，こ れらの二者の平均值を比較すると有意の差が認め られた。次にこれらのイヌに幽門部漿膜筋層切離 術を付加すると $33.2 \pm 20.0 \%$ となり，近側胃切 除兼幹迷切イヌとの間には有意の差を認めなかっ た. $\left(\mathrm{t}_{25}=2.43, \mathrm{P}<0.025\right), \quad(\mathrm{t}=0.64, \mathrm{p}>1)$. 表 3 には空腹時伝播速度を示した。近側胃切除後 残胃での正放電時の電極 $\mathrm{E}_{1}$ から $\mathrm{E}_{4}$ までの伝播 速度の平均は $0.70 \pm 0.04 \mathrm{~cm} / \mathrm{sec}$ であった。これ らのイヌに幹迷切を加えると $0.67 \pm 0.04 \mathrm{~cm} / \mathrm{sec}$ となり，二者間には有意の差を認めなかった。さ らに幽門部漿膜筋層切離術を付加すると0.64土 $0.04 \mathrm{~cm} / \mathrm{sec}$ となり近側胃切除イヌと, また近側

表 2. Dysrhythmia の出現頻度

\begin{tabular}{l|c|c|c}
\hline & $\begin{array}{c}\text { proximal } \\
\%\end{array}$ & $\begin{array}{c}\text { prox+TV } \\
\%\end{array}$ & $\begin{array}{c}\text { prox+TV +PP } \\
\%\end{array}$ \\
\hline Dog 1 & $12.2 \pm 4.3$ & $34.5 \pm 25.3$ & $39.3 \pm 23.5$ \\
Dog 2 & $13.0 \pm 8.9$ & $22.7 \pm 20.9$ & $26.4 \pm 17.4$ \\
Dog 3 & $26.5 \pm 18.0$ & $71.5 \pm 14.8$ & $30.3 \pm 15.5$ \\
\hline 平 均 & $16.8 \pm 13.1$ & $40.4 \pm 28.9$ & $32.2 \pm 20.0$ \\
\hline
\end{tabular}

表 3. 空腹時の伝播速度

\begin{tabular}{l|c|c|c}
\hline & $\begin{array}{c}\text { prox } \\
\mathrm{cm} / \mathrm{sec}\end{array}$ & $\begin{array}{c}\text { prox+TV } \\
\mathrm{cm} / \mathrm{sec}\end{array}$ & $\begin{array}{c}\text { prox+TV }+\mathrm{PP} \\
\mathrm{cm} / \mathrm{sec}\end{array}$ \\
\hline Dog 1 & $0.70 \pm 0.05$ & $0.70 \pm 0.04$ & $0.65 \pm 0.03$ \\
Dog 2 & $0.79 \pm 0.04$ & $0.74 \pm 0.05$ & $0.69 \pm 0.05$ \\
Dog 3 & $0.62 \pm 0.03$ & $0.59 \pm 0.02$ & $0.60 \pm 0.03$ \\
\hline 平 均 & $0.70 \pm 0.04$ & $0.67 \pm 0.04$ & $0.64 \pm 0.04$ \\
\hline
\end{tabular}

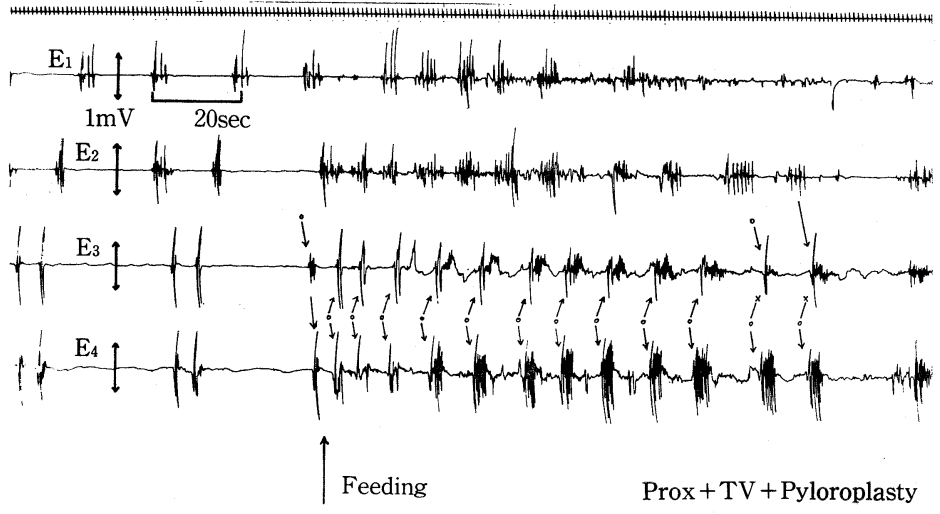

図 7. 近側胃切除, 幹迷切, 幽門部漿膜笳層切離術イヌの摂食直後の筋電図. 掑食前の放電間隔 20 秒前後であるが摄食後は極端な短縮と乱れが出現 し, $\mathrm{E}_{3} \mathrm{E}_{4}$ 間への移動をみる. 
胃切除兼幹迷切イヌとの間にはいずれも有意の差 を認めなかった。 $\left(\mathrm{t}_{4}=0.4, \mathrm{p}<1\right),\left(\mathrm{t}_{4}=0.33, \mathrm{p}<\right.$ 1), $\left(\mathrm{t}_{4}=0.60, \mathrm{p}<1\right)$.

\section{II. 摂食後の筋電図と歪曲線}

近側胃切除イヌ胃の掑食直後の筋電図は放電間 隔の短縮とその不整化, 及び dysrhythmia の頻 発を示した（図 7 ) が，この状態は数分後に消失 した。しかし 15 分後にはほら゙一定の放電間隔を 保ち， $\mathrm{E}_{1}$ より $\mathrm{E}_{4}$ に整然と伝播する基本的電気律 動と, 強い活動電位を伴っているのが認められた (図 8 ). 摂食後の放電間隔の変動は空腹状態での $18.5 \pm 3.6 \mathrm{sec}$ から摂食後 15 分で $13.3 \pm 1.3 \mathrm{sec}$, 30 分で $12.7 \pm 0.3 \mathrm{sec}, 45$ 分で $13.1 \pm 1.4 \mathrm{sec}, 60$ 分で $12.6 \pm 0.4 \mathrm{sec}$ となり空腹時と比較すると著
明に減少するのが認められた。 $\left(t_{21}=6.9, \mathrm{p}<\right.$ $0.005), \quad\left(\mathrm{t}_{21}=3.82, \mathrm{p}<0.005\right.$ 以下 $), \quad\left(\mathrm{t}_{20}=4.33\right.$, $\mathrm{p}<0.005$ )（図9）。 またこれらのイヌに幹迷切を 付加すると空腹時の 18.2 土4. $1 \mathrm{sec}$ から摂食後 15 分で $12.7 \pm 1.2 \mathrm{sec}, 30$ 分で $12.5 \pm 0.9 \mathrm{sec}, 45$ 分 では $12.0 \pm 0.6 \mathrm{sec}, 60$ 分で $12.9 \pm 1.2 \mathrm{sec}$ と同様 の減少がみとめられた $\left(\mathrm{t}_{14}=6.28, \mathrm{p}<0.005\right)$, $\left(\mathrm{t}_{14}=5.7, \mathrm{p}<0.005\right), \quad\left(\mathrm{t}_{14}=6.65, \mathrm{p}<0.005\right)$, $\left(\mathrm{t}_{14}=5.17, \mathrm{p}<0.005\right)$.

幽門部漿膜筋層切離術付加後にも同様な傾向が みられた。即ち空腹時 $19.5 \pm 3.3 \mathrm{sec}$ ，摂食後 15 分で $12.7 \pm 0.7 \mathrm{sec}, 30$ 分で $13.2 \pm 0.8 \mathrm{sec}, 45$ 分 で $13.7 \pm 0.9 \mathrm{sec}, 60$ 分で $13.5 \pm 0.6 \mathrm{sec}$ であっ た. $\left(\mathrm{t}_{10}=9.11, \mathrm{p}<0.005\right), \quad\left(\mathrm{t}_{11}=7.64, \mathrm{p}<\right.$

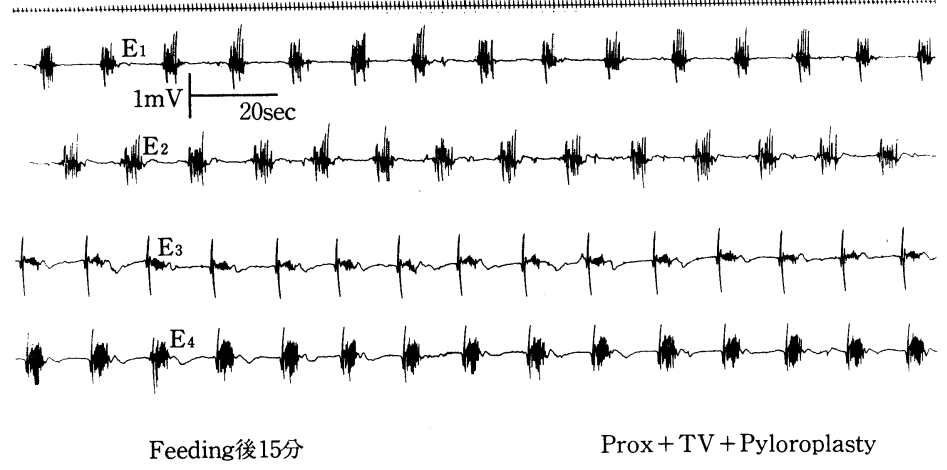

図 8. 近側胃切除, 幹迷切, 幽門部漿膜筋層切離後, 摂食後 15 分の筋電図. 放電間隔 13 秒前後のほぐ規則正しい電気活動となる。また dysrhythmia も消失する。

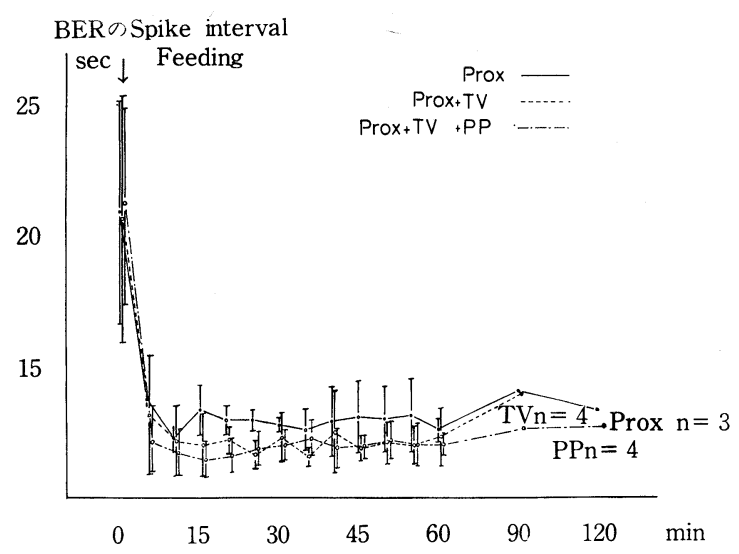

図 9. 掑食後の放電間隔.

摂食前 21 秒前後であった放電間隔が摄食後には極端 に短縮した。この現象は幹迷切付加後にも,さらに幽 門部漿膜筋層切離付加後にも認められた。 
$0.005), \quad\left(\mathrm{t}_{11}=6.5, \mathrm{p}<0.005\right), \quad\left(\mathrm{t}_{11}=6.75, \mathrm{p}<\right.$ 0.005). 乙か乙近側胃切除群之幹迷切群, 幹迷切 群之幽門部漿膜筋層切離群, 近側胃切除群之幽門 部漿膜筋層切離群との間には有意の差を認めなか った。

一方 dysrhythmia は術後数日から 2 週間以内 では摂食によっても消失せず, 頻発することが多 い.しかし 3 週間以後では摂食によって空腹時に 頻発していた dysrhythmia は消失した。この所 見は幹迷切後も，木た幽門部漿膜筋層切離術後に も同様にみられた。次に個々のイメの摄食後電気 活動の伝播速度を示す.この平均值は摂食前 0.70 $\pm 0.04 \mathrm{~cm} / \mathrm{sec}$ で摂食 30 分では $0.63 \pm 0.06 \mathrm{~cm} /$ sec, 45 分では $0.64 \pm 0.05 \mathrm{~cm} / \mathrm{sec}, 60$ 分では 0.62 $\pm 0.05 \mathrm{~cm} / \mathrm{sec}$ となった. これらのイヌに幹迷切 を加えると摂食後 30 分で $0.57 \pm 0.03 \mathrm{~cm} / \mathrm{sec}, 45$ 分では $0.57 \pm 0.02 \mathrm{~cm} / \mathrm{sec}, 60$ 分で $0.59 \pm 0.03$ $\mathrm{cm} / \mathrm{sec}$ であった。 また幽門部漿膜筋層切離術を 付加すると 30 分では $0.60 \pm 0.05 \mathrm{~cm} / \mathrm{sec}, 45$ 分で は $0.61 \pm 0.02 \mathrm{~cm} / \mathrm{sec}, 60$ 分では $0.60 \pm 0.05 \mathrm{~cm} /$ secであった（表 4). すなわち伝播速度は摂食に より遅くなる傾向を示したが，術式による变化は みられなかった。

\section{III. インスリン投与時の筋電図と歪曲線}

レギュラーインスリン $0.4 \mathrm{U} / \mathrm{kg}$ を静脈内投与 後には迷走神経幽門洞枝温存例では投与直後より

表 4. 食後の伝播速度

\begin{tabular}{c|c|c|c|c}
\hline \multicolumn{1}{c|}{} & & 30 分後 $\mathrm{cm} / \mathrm{sec}$ & 45 分後 $\mathrm{cm} / \mathrm{sec}$ & 60 分後 $\mathrm{cm} / \mathrm{sec}$ \\
\hline \multirow{3}{*}{ Dog 1 } & proximal & $0.66 \pm 0.04$ & $0.66 \pm 0.08$ & $0.61 \pm 0.01$ \\
& prox+TV & $0.55 \pm 0.02$ & $0.53 \pm 0.01$ & $0.57 \pm 0.03$ \\
& prox+TV+PP & $0.63 \pm 0.05$ & $0.64 \pm 0.02$ & $0.61 \pm 0.05$ \\
\hline \multirow{3}{*}{ Dog 2} & proximal & $0.71 \pm 0.04$ & $0.71 \pm 0.01$ & $0.71 \pm 0.01$ \\
& prox+TV & $0.66 \pm 0.02$ & $0.66 \pm 0.01$ & $0.64 \pm 0.01$ \\
& prox+TV+PP & $0.66 \pm 0.02$ & $0.67 \pm 0.01$ & $0.63 \pm 0.03$ \\
\hline \multirow{3}{*}{ Dog 3 } & proximal & $0.52 \pm 0.08$ & $0.54 \pm 0.04$ & $0.54 \pm 0.12$ \\
& prox+TV & $0.52 \pm 0.03$ & $0.51 \pm 0.02$ & $0.57 \pm 0.03$ \\
& prox+TV+PP & $0.53 \pm 0.05$ & $0.53 \pm 0.02$ & $0.55 \pm 0.05$ \\
\hline
\end{tabular}

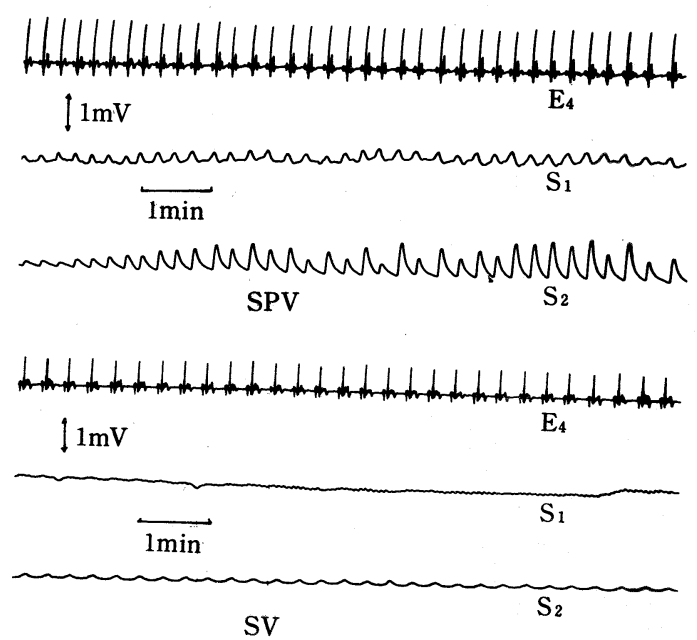

図 10. インスリン投与後の基本的電気律動と歪曲線. 選近迷切時の電気活動ではインスリン投与後 20 分前 後から著明な活動電位が出現し，歪曲線上，著明な 収縮運動をみとめる。このイヌに選迷切を付加し， 同様な刺激を加えると上記の変化は出現しなかった。 


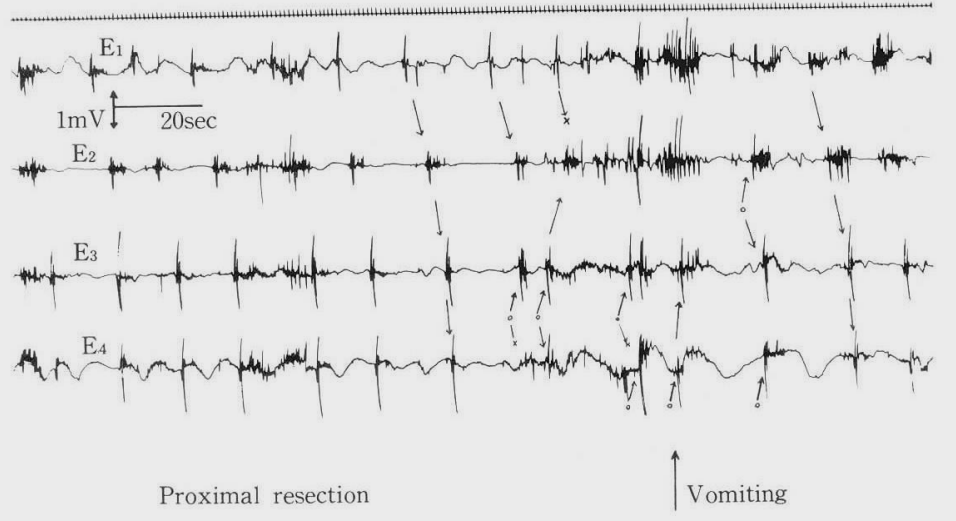

図 11, 近側胃切除術後嘔吐時における等電図.

幽門洞部に phase lead があり， 口側への伝播がみとめられる。

20 分前後まで反心はないが，これ以後血糖伹の 低下にしたがって企曲線上収縮運動が増強しはじ め 30 分前後で最強となった。インスリン静脈内 注射後 20 分後の筋電図と歪曲線を図 10 に示す。.

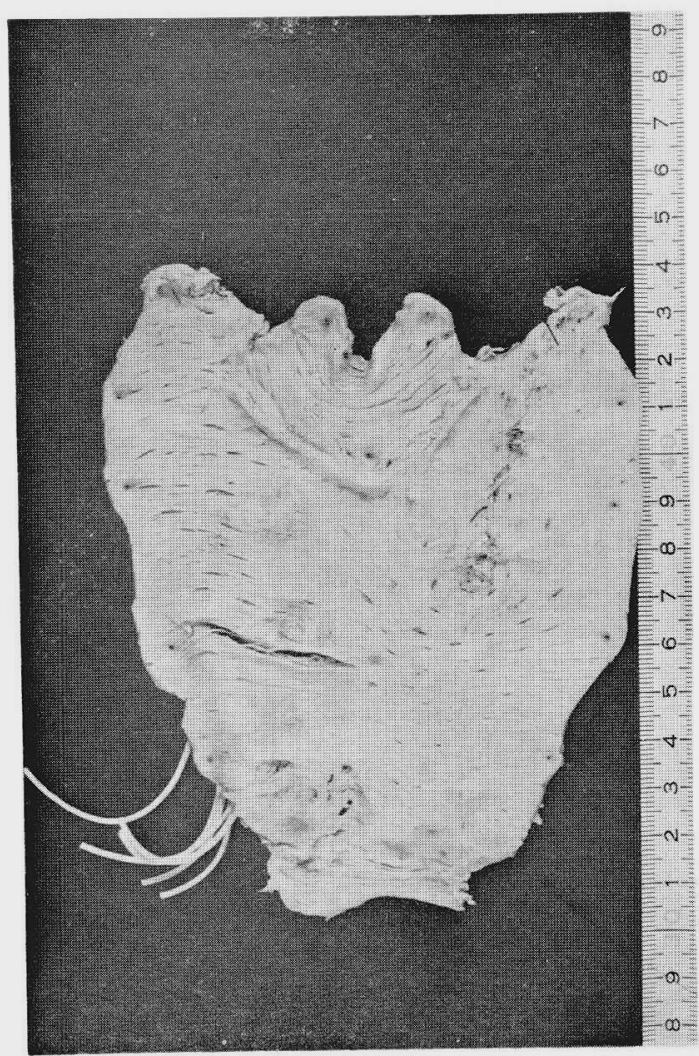

図 12. 近側骨切除術々後残胃竻㞓棈築像. 残胃に少量の斜走筋束部力残つているにすぎ ないことを示す。
伝播速度をみると運動と一致して速くなる傾向に あった。この変化は選迷切後には全く消失してい た (図 12 下段).

\section{IV。嘔吐時の筋電図}

近側胃切除後にはしばしば呕吐がみららる。呕 吖侍には筋電図上幽門洞部に dysrhythmia がみ られた（図 11）。すなわち $\mathrm{E}_{1}$ より $\mathrm{E}_{4}$ に整然と伝 播していた電気活動が幽門洞部に発生した異所性 の電気活動によってさえぎられ，その電気活動が

摘出標本筋層図

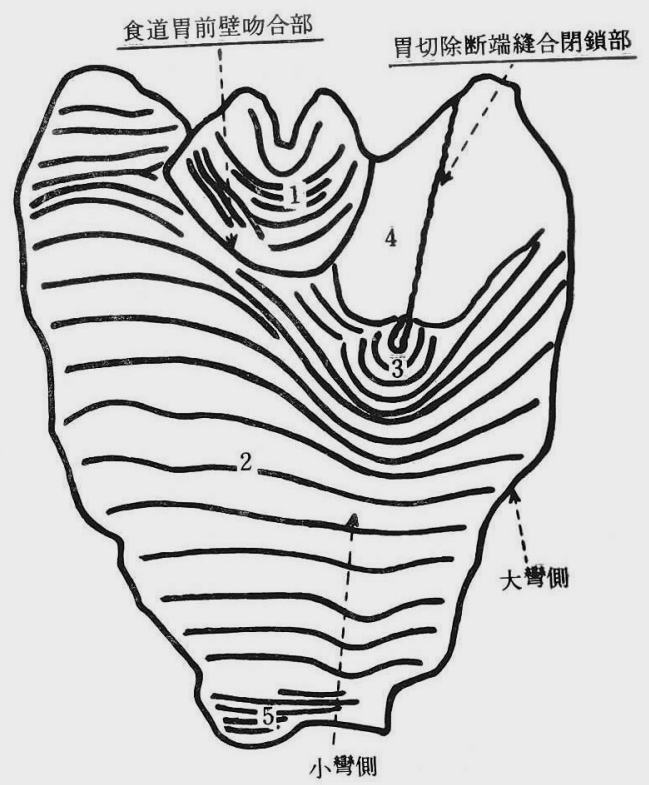

図 13, 図 12 の筋構筑像の㷬式図

1. 食道輸状筋。2. 幽門洞部輸状盼。3, 境界輸 状筋束. 4. 斜走筋束. 5 , 十二指腸輸状筋 
$\mathrm{E}_{1}$ に，すなわち口側に向って伝播している。こ のよらな電気活動は無処置胃の空腹時にも認めら れるが，近側胃切除後では頻発した。

\section{V. 近側胃切除後のイヌの食事摂取量}

手術直後は手術の影響のため少量のミルクをも 摂取しない。しかし以後回復と共にミルク掑取量 は呕吐を反復しながらではあるが増加した。5日 目頃からほ心゙ $180 \mathrm{ml}$ の牛乳を摂取し, 多くの場 合呕吐をしない.さらに数日後からドッグフー ド, ラーメン混合物 $200 \mathrm{~g}$ までは呕吐せずに摂取 するよらになる。この状態は 8 日目前後から变ら ず観察された。すたこのイヌに幹迷切を付加して も同様であった。しかしこのイヌに幽門部墏膜筋 層切離術を付加するとドッグフード，ラーメン混 合物摂取量は約 $50 \%$ 增加したが，これ以上摂取 すると呕吐した。幽門部漿膜筋層切離術は食事捸 取量を增加することができたが呕吐を防止するこ とは出来なかった。

\section{VI. 摘出標本の解剖学的並びに病理組織学的所見}

摘出標本（図12），打よびその模式図（図 13）

\section{考}

友田ら（1950）は積桠的に胃全剔術を行った後 に消化吸収不全や悪性貧血などの術後障害が叔こ ることを認め，できるだ讨胃を残す術式の重要性 をみとめている。久留 (1952) 扰よび水上 (1952), 砂田（1952）らは噴門側切除によって胃の幽門側 を残す術式を報告したが，てれ以来胃良性疾患に も積極的にこの術式が応用されるよらになった。 しかしこの術式を行った後に起こる逆流性食道 炎, 臙下障害, 残胃内容の排出障害等の問題が Tanner (1951), Franke (1959)，梖 (1959) に 指摘され，この術式に伴ら術後愁訴が新しい問題 として注目された。

これらの問題を残胃運動機能からとらえる試み から,この障害が近側胃切除に際して迷走神経が 切離されることによって胃アトニー Tanner (1951)，あるいは幽門症變 Franke (1959) に起 因するとの考え厅が報告された。渡辺（1959）は 近側胃切除兼迷切で幽門部機能が完全な失調にい たることをみとめ，等電図学的には胃は主として 驰緩的であるが時に㽷鑾状態を示すものがあり迷 走神経を温存すると正常の胃運動に回復するのが

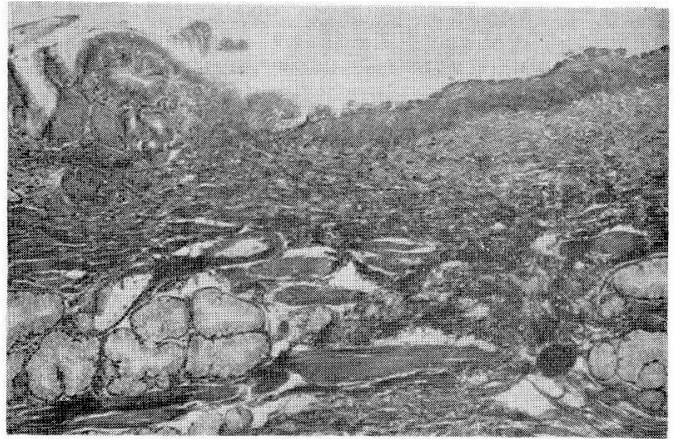

図 14. 摘出標本食道末端部の病理組織学的所見. $(\mathrm{H}$. E. $\times 50)$

角化扁平に皮の一部が薄くなり，父部位によ っては遊離がみられる。粘膜下組織には細胞 浸潤をみとめ，食道炎存みとめる。

から残胃は泟とんど幽門部輪状筋からなり，一部 に斜走筋束を残すのみである。又全例に扑てて食 道末端部組織は上皮の们化届平上皮が一部薄くな りまた部位によっては遊離がみられる。粘膜下 組織には細胞浸潤をみとめ, 食道炎が存在してい 万(図 14).

\section{察}

早く，食道炎も認めないと報告している。また鳴 海 (1964)，小野 (1964)，木村 (1972) 坆胃に 执いては打そらく迷切により胃内容排出の主役を な与幽門前庭部，括約筋部に括ける協同運動の失 調ぶ招来され，そのため胃内容の停滞が生じるも のと述ベている。いずれにしても術後の胃運動障 害の原因学迷切に求めている。

しかし槙，白鳥ら（1965），(1966）は迷走神経 が残胃運動を梘制していると与れ壮近側胃切除, すなわち迷切後の胃運動は切除範囲に関係なくに ぶ同様の連動を示すべきであるとした。

しかし噴門側胃の切除範四が広い程残胃の運動 が立進することを認めて，迷切による影響といら よりは胃壁の切離といらことに残胃運動規制因子 を求めている。西島ら（1968）悢道胃吻合口を バルーンで閉塞することによって幽門前庭部の蠕 動性収縮状態が注ぶ正常例と同様になり幽門の流 通障害がなく，前庭部収縮相に伴って胃内容の十 二指腸への排出䒚涩めるとのことから，噴門切除 後にみられる障害は噴門括約機能の脱落による胃 内圧形成維持能力の障害にもとずくものとしてい 
る. 著者の行なった空腹時の筋電図学的観察で は, 幽門洞技を温存した場合, 近側胃切除直後か ら数日間は放電間隔の延長を認めないが, 以後回 復するに従って徐々に延長し約 $2 \sim 3$ 週間後に安 定した。この慢性期の放電間隔は $20 \mathrm{sec}$ 前後で桑 島ら（1976）の発表した 無処置胃の 10.8～13.7 secに比較して著明に延長しており放電間隔の変 動も著明であった。

一方胃壁の丕曲線から検討すると dysrhythmia の見られない時は汪ぶ2〜15 分ごとに，1ないし 5 コの強い収縮運動が反復して認められたが, 乱 れの発生頻度が高くこのような収縮が見られるこ とは少なかった。これらのことから空腹時の胃運 動は無処置胃のそれに比較して乱れが多く, 減弱 していると考兄られる. Kelly \& Code (1974) が 行った胃底部切除では放電間隔は無処置のそれと の間に差が認められなかったことを報告している が，これは噴門側胃の切除量が少ないこと, 食道 胃噴門部の切除を行っていないためと考えられ る. 次に近側胃切除を施行したイヌに食物を与兄 ると, 無処置胃に特汀る桑島ら（1976）の云う放 電間隔の延長はなく, むしろ $30 \%$ 前後の短縮と 強い活動電位を伴った基本的電気律動がみとめら れた，又歪曲線上では筋電図上整然とした活動電 位に一致して収縮運動が見られた．以上のことか ら, 摂食後の残胃の Tanner (1951) の云ら胃アト ニーは考兄らない.また㮁 (1965), 梖ら (1966) の云う逆蠕動発生に伴ら幽門部の異常興奮も認め られなかった。

この相違は胃の切除範囲の広さと関連している のかも知れないが，槙の急性実験とは明らかに条 件を異にしている．次に幽門病攣の有無について みると著者の実験から前庭部に摂食直後にごく一 過性の dysrhythmia をみとめたが，この現象は 急激な胃壁伸展によって若起せられた幽門洞部の 一時的異常興奮と考兄られる。しかし筋電図上継 続して発生することはなく徐々に整然としたリズ ムに回復した。このことから幽門痤攣が dysrhythmia を意味するとすれば，いわゆる幽門症攣は 空腹時, 摂食直後の数分を除いてはみられなかっ たことになる。

次に平島ら（1966）は近側胃切除後残胃運動機 能と胃の蠕動発生の機序の解明の目的でバルーン 法による内圧測定を行ない, 近側胃切除後残胃運
動は休止期のない運動期のみで, 蠕動波は等高, 等間隔性の調律波であり, 残胃の大きさに逆比例 して波高が高くなる傾向を示すとし，このことを 迷走神経支配の脱落による残胃壁在神経節の自動 能の支配のための自動運動と考兄ている。平島ら （1966）の実験は胃壁をバルーンによって持続的 に刺激を加えていることになり，著者の摂食実験 と考えあわせればその機序が同様であることから 理解できる・

著者の行なった近側胃切除後の歪曲線上の観察 では幽門洞枝の温存例と幹迷切例の両者間には収 縮運動に差を認めなかったが，選近迷切では幽門 洞枝温存によって幽門洞部の胃壁の収縮運動は無 処置胃におけると同様の waxing and waning の パターンを維持するといら桑島（1977）の実験報 告がある。しかし近側胃切除残胃での空腹時の dysrhythmia 発生頻度は幽門洞枝を温存すること で減少するが，摂食後は迷切に関係せず消失する ことから, 残胃運動は迷走神経よりはむしろ壁在 神経節に影響をらけているものと考えられる。横 山（1968）は，胃は拡張刺激部位により反応が異 なり幽門洞部刺激時に一番強い蠕動運動と逆蠕動 をみとめ, 又電気活動では放電間隔の延長, 伝播 速度の增加, 逆蠕動放電の頻発等を観察し, 野崎 （1969）も同様の所見を述べている。しかし著者 の行った近側胃切除イヌの摂食後では幽門洞部拡 張刺激と同様な刺激と考号られるにもかかわらず 横山（1968），野崎（1969）らの実験結果とは逆 に放電間隔の短縮, 乱れの減少ないし消失がみら れた。同様な現象が胃横切再吻合の際にもみられ 横切下部胃に拈いて延長した放電間隔が摄食刺激 により短縮することが森下ら（1976）により認め られている。

一方この現象は蔵本ら（1975）の胃ペーシンング 実験によって明らかにされたよらに幽門洞部のぺ ースレートは体部のそれに比較して高くなること から証明出来るかも知れない。一方噴門側切除は 食道胃接合部に存在する逆流防止機構, (蔵本, 1961）を切除することにある. この切除によって 起こる逆流性食道炎や胃内容の排出障害の原因 は Tanner (1951), Franke (1959) 等の報告もみ られるが，まだ結論をみていない。梖ら（1965, 1966）は胃横切離端々吻合術後に高頻度に逆蠕動 を認め,これに幽門形成術を施行すると逆蠕動放 
電が減少し正蠕動放電の出現が増加したことから 幽門形成術は肉眼的にみて胃動運を弱勢化させ， 逆蠕動の発生に対してこれを抑制するように作用 すると述べているが，森下ら（1976）の胃横切慢 性実験では術後逆放電は数日間続くが次第に減少 し，その後全例に上部胃の放電に追従した正放電 を認めている.

また著者が施行した幽門部漿膜筋層切離術後の 逆放電発生頻度は術前と比較して有意の差を認め なかった。すなわち幽門形成術そのものは胃の活 動電位には大きな影響を与えないものといえる。

これらの実験結果の相違は実験方法の相違，す なわち急性実験と慢性実験の相違によるものかも 知れない、鳴海（1964）は胃底部切除後における 幽門括約笳の切離はX $\mathrm{X}$ 線透視下において低運動状 態にある幽門部の内腔を機械的に拡張することに よって内容排出の遅延が改善され, その結果食道 への逆流を防止できると述べている，大井ら （1966）は幽門形成術，又は幽門漿膜筋層切離術 は幽門内腔の拡大といらことであり蠕動による排 出力はむしろ減弱していることを認めている．著 者の実験では, 近側胃切除イメは $200 \mathrm{~g}$ まで嘔吐 せずに摄取したが，これ以上摂取すると嘔吐し た．筋電図学的には幽門症攣と考えられる現象と は判定し難いが，幽門洞部には明らかに嘔吐時に dysrhythmia が認められた。こっで幽門筋切離を 行らと食物摄取量は形成前と比較して $50 \%$ 前後 まで増量した。それ以上食物を摄取すると幽門部 漿膜筇層切離以前と同様の嘔吐時の電気活動を示

\section{ま}

1. 近側胃切除術後の残胃の放電間隔は正常胃 の放電間隔に比較して延長した。またこの延長は 幹迷切付加, 幽門部漿膜筋層切離付加後にも変化 を受けなかった。

2. 近側胃切除術後の空腹時には dysrhythmia が頻発し, 正常胃の発生率 $1.7 \%$ 以内に比較して $16.8 \pm 13.1 \%$, 幹迷切付加後 $40.4 \pm 28.9 \%$, 幽 門部漿膜筋層切離術後 $32.2 \pm 20.0 \%$ と多発し, 近側胃切除等と幹迷切群との間には有意の差を認 めた。すなわら迷走神経は空腹時胃の dysrhythmia の発生を抑制すると云える。しかし幹迷切 群と幽門部漿膜笳層切離群との間には有意の差を 認めなかった。
し，嘔吐した。これらのことから筋電図上放電間 隔, 伝播速度, 胃壁収縮形式等は空腹時と摂食後 のいずれの場合にも幽門部漿膜筋層切離前後で著 変を認めないことから幽門部漿膜笳層切離（形成 術）はある程度の食物摂取量を増加せしめること が出来るが，胃の電気活動そのものには影響を与 点ないものと考觉られる。すなわち逆流現象は胃 蠕動によりもたらされる胃内压の上昇に対し逆流 を防止する噴門括約作用の脱落により起ってくる もの之考えられ, 残胃に相応の適量摂取では摂食 直後に一過性の dysrhythmia がみられるが胃内 压の上界が弱いため呕吐をみないと考えられる。 この点から近側胃切除は胃内腔の減少と共に胃内 圧の維持力の低下から摂取量を異常に減少させる といえる。

一方このことは西島ら（1968）が述べるごとく 胃内圧形成維持能力の障害が逆流の原因となって いることを示唆しているが, 近側胃切除術後の愁 訴は噴門括約作用と胃貯留能の喪失によるもので あり，幽門括約筋の切開もしくは幽門形成術のみ では解決されるものではない。

一方これらの対策として逆流防止升機能の作 成方法として Fundic patch 法 (Thal-Hatafuku, 1975），落下傘吻合（西ら，1955），空腸の食道胃 間への移植 (Melendino, 1955), (Skinner, 1955), (Sirak，1954)，分節運動による逆流防止（井口， 1964), 回盲部移植（円山，1971）等種々の術式 が考案されているが一長一短があり, 今後この逆 流防止機構の完全な術式の開発が望まれる。

と

3. 基本的電気律動の伝播速度は, 近側胃切除 術群と幹迷切付加群, 幽門部漿膜筋層切離付加群 との間に有意の差はなかった。

4. 摄食により, 近側胃切除術群, 幹迷切付加 群, 幽門部漿膜筋層切離付加群共に著明な伝播速 度の減少をみるが，それぞれの間に有意の差は認 めなかった。

5. Dysrhythmia の頻度は摄食により，近側胃 切除術群, 幹迷切付加群, 幽門部漿膜筋層切離付 加群のいずれの場合にも消失し，それぞれの間に 差は認めなかった。

6. 近側胃切除術後幽門部漿膜筋層切離を付加 することにより 1 回の摂食量を増加させることが 
出来た。しかし筋電図上には変化はみられなかっ た.

本論文の要旨を日本消化器病学会中国四国第 25 回地方
会, 第 16 回, 第 17 回日本平滑筋学会総会で報告した。 稿を終るにあたりご校閲とご指導を賜わりました恩師古 味信彦教授, 桑島輝夫助教授, 蔵本守雄講師に心から謝意 を表します。

\section{文献}

Franke, H.U. and Ney, H.R. (1959). Die Chirurgie des Kardiacarcinomas, ein Problem der Frühdiagnose und der Refluxoesophagitis. Chirurg. 30: 152-157.

平島 毅 (1966)。噴門側切除後残胃運動機能の検討. 臨床外科, 21 (9) : 49 58.

Holle, F. and Heinrich, G. (1955). Subdiaphragnatic fundersectomy in gastric surgery. Surgery 101 : 385-394.

井口 潔 (1964)。胃手術後の逆流性食道炎. 外科治療 $10: 381-391$.

Kelly, K.A. and La Force R.C. (1972). Pacing the canine stomach with electric stimulation. Am. J. Physiol. 222: 588-594.

Kelly, K.A. and Code, C.F. (1974). Effect of gastric fundectomy on canine gastric electrical and motor activity. Amer. J. Physiol. 226: 1445-1449.

木村克明 (1972). 近側胃切除後にお污万残胃運動の映像工学的観察. 日平滑笳誌 $8: 112 \sim 125$.

古根川龍司 (1975)。胃平滑筋及電図の dysrhythmia について。 日平滑势誌 $11: 255-256$.

古根川龍司ら (1974)。胃運動に扔ける迷走神経幽門洞枝の役割。 日平滑笳誌 $10: 230-231$.

蔵本守雄 (1975)。胃平滑筋電気活動のペーシングについて。 日平滑筋誌 $11: 253-254$.

蔵本俊吉 (1961)。食道胃移行部及びその付近に於々る胃内容の逆流防止機構注関する研究。日外会誌 6:615625.

久留 勝, 水上哲次 (1952)。余等の行いつ>ある噴閏切除術式に就いて。 日外会誌 $\mathbf{5 7}:$ 505-506.

桑島輝夫 (1977). 各種迷切のイヌ胃運動に及浔す影響についての研究. 日平滑筋誌 13: 55-67.

桑島煇夫ら (1976)。 イ邓の正常胃筋電図と收縮運動. 日平滑筋誌 $12: 1-8$.

Leger, L. \& Kanocci. F, (1953). La gastrectomie fundique. Press Med. 61: 962-964.

䧺 哲夫 (1965). 近側胃切除をめぐる 2, 3 の問題. 治療 47:789-793.

槙 哲夫, 伊藤良己 (1959)。横隔膜下胃底部切除術について。手術 13:915-923.

㮩 哲夫, 白鳥常男, 山口嚴ら (1966)。近側胃切除術式の検討一特に幽門成形術の必要性について一。手術

$20: 45-51$.

寣 哲夫, 白鳥常男, 金子靖征 (1968)。噴門の機能, 特に逆流防止機能について。治療 $\mathbf{5 0}: 2793-2746$.

桭 哲夫，鈴木泰三 (1966). 平滑筋々電図の基礎と臨床. 金原出版

円山八郎 (1971)。代用胃形成術. 外科治療 $24: 186-195$.

Melendino, K.A. and Dillord, D.H. (1955). The concept of sphincter substitution by an interposed jejunal segment for anatomic and physiologic abnormalities at the esophagogastric junction. Ann. Surg. 192: 486-569.

森下和哉 (1976)。横切後再吻合胃のベーシングについて。 日平滑筇誌 $12: 298-300$.

村上忠重 (1976)。胃の外科の盲点, 外科 18:706-709.

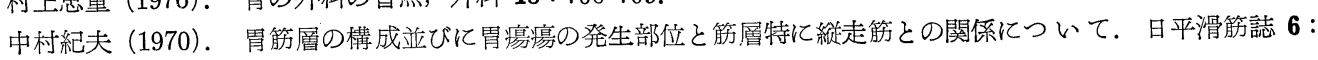

245-262.

鳴海裕行 (1964 a)。胃括約筋機能々胃内容排出機転についての電気生理学的研究. 最新医学 19:2539-2547.

鳴海裕行 (1964b). 胃括約䇨機能乙胃内容排出機転についての電気生理的研究. 最新医学 19:3302-3308.

西 満正 (1970)。近側胃切除術に打溥式の検討. 外科治療 $23: 290-305$.

西島早見 (1968). 噴門切除術に関する研究, とくに残胃の機能よりの検討. 外科 $30: 1549-1559$.

野崎 修 (1969)。 各種胃切除術後认お汀る胃内容排出機転について I 報, II 報。 日平滑笳誌 5 : 9-18. 日平滑 筋誌 $5: 19-26$.

小野慶一 (1964)。横隔膜下胃底部切除術と幽門部括約機能, 外科治療 $11: 127-144$.

大井 実 (1966)。幽門機能について. 外科 $28: 1326-1332$.

Sarna, S.K., Daniel, E.E. and Kingman, Y.J. (1972). Premature control potentials in the dog 
stomach and in the gastric conputer model. Am. J. Physiol. 222: 1518-1523.

Sirak, et al. (1954). An evaluation of jejunal and colic transplants in experimental esophagitis. Surgery 36: 399-411.

Skinner, H.H., and Merendino, K.A. (1955). An experimental evaluation of an interposed jejunal segment between the esophagus and the stomach chombined with upper gastrectomy in the prevention of esophagitis and jejunitis. Ann. Surg. 141: 201-207.

砂田輝武 (1952). 余等の行いつ〉ある噴門切除術式について. 追加. 日外会誌 $7: 506$.

Tanner, N.C. (1951). Neue Probleme der Magen-chirurige. Langenbecks Arch.u. Dtsch. Z. Chir., 267: 369-373.

Thal, A.P., Hatafuku, T., and Kurtzman, R. (1965). A new method for reconstruction of the esophagogastric junction. Surg. Gynecol. \& Obstet. 120: 1225-1231.

友田正信 (1950)。胃癌に文する胃全摘手術適応の拡大に就て．臨外 $5: 189-195$.

渡辺裕一 (1959)。迷走神経切断後の胃, 特に幽門括約部機能主として活動部位による研究. 東北医誌 60：576593.

横山成樹 (1968)，胃の各部の拡張刺激と幽閏機能に関する研究. 日平滑筋誌 $2:$ 183-190.

(受付 1978 年 4 月 11 日) 